\title{
Approaches to characterization of radioactive waste in Ukraine at interrelated steps of their management
}

\section{- larmosh I.}

State enterprise «State Scientific and Technical Center for Nuclear and Radiation safety», Kyiv, Ukraine

ORCID: https://orcid.org/0000-0002-1816-3399

- Kondratiev S.

State enterprise «State Scientific and Technical Center for Nuclear and Radiation safety», Kyiv, Ukraine

ORCID: https://orcid.org/0000-0003-2405-4313

\section{- Kuechler L.}

Gesellschaft für Anlagen- und Reaktorsicherheit (GRS) gGmbH, Berlin, Germany

- Tokarevskyi 0.

State enterprise «State Scientific and Technical Center for Nuclear and Radiation safety», Kyiv, Ukraine

ORCID: https://orcid.org/0000-0002-1064-7911

\section{- Solovyov 0.}

State enterprise «State Scientific and Technical Center for Nuclear and Radiation safety», Kyiv, Ukraine

ORCID: https://orcid.org/0000-0002-4811-0861

A key point for safety assessments at different steps of radioactive waste (RW) management is the knowledge of all the relevant properties of materials that are to be disposed of as RW or cleared from regulatory control (immediately or after a certain period of time for decay storage). Characterization is the basis for the determination of radiological and non-radiological hazards of the radioactive materials and waste.

This paper considers approaches for a systemized characterization of radioactive waste at all steps of its management from generation to disposal. These approaches ensure safe radioactive waste management at each step and the compliance of the final radioactive waste product with the established requirements.

The provided information is based on the "Guideline for characterization, accounting and control of radioactive waste", which was developed jointly by experts from SSTC NRS and RISKAUDIT.

Keywords: radioactive waste characterization, Guideline, methodological approach, recommendations, RW management, radiological properties, physical properties, chemical properties.

(C) larmosh I., Kondratiev S., Kuechler L., Tokarevskyi O., Solovyov O., 2020

\section{Introduction}

The need for further development of a comprehensive system for radioactive waste management in Ukraine is reflected in Ukrainian regulations, among others in the Law of Ukraine "On the State Target Environmental Program on Radioactive Waste Management" [1] and General Safety Provisions for Predisposal Radioactive Waste Management [2]. These laws and regulations define general safety requirements and the main areas of RW management improvements, in particular, during RW management at places of its generation, at RW processing facilities and for long-term storage and disposal facilities for RW.

The international framework for determination of RW characterization requirements is represented by the international treaties (Conventions), including 
"Joint Convention on the Safety of Spent Fuel Management and on the Safety of Radioactive Waste Management" [3] and "Convention on Nuclear Safety" [4] and by other documents like those of IAEA [5 - 7] and European Union [8, 9]. In particular, [5] describes allocation of responsibilities of different stakeholders in the field of RW characterization (see Fig. 1).

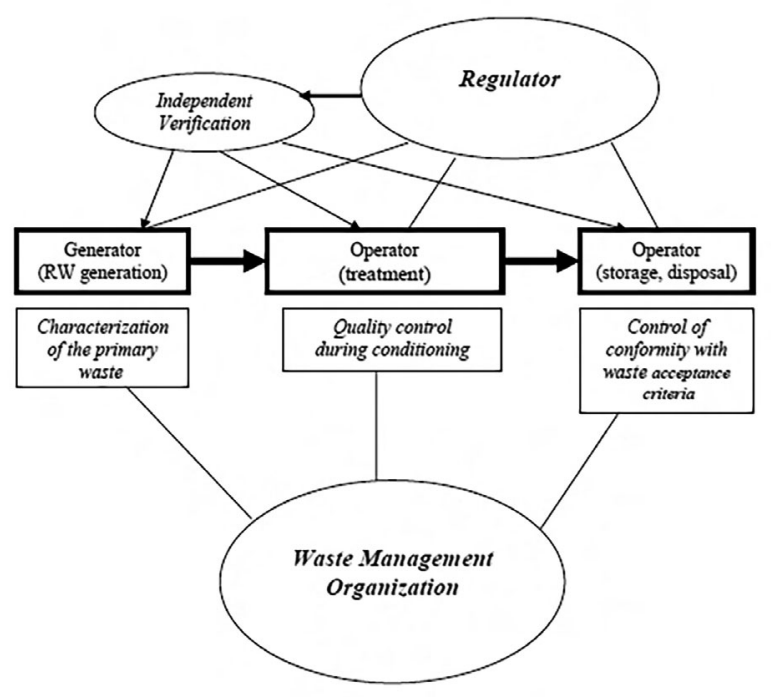

Figure 1 - Diagram showing responsibilities of various players in a waste characterization programme [5]

There is on-going development in Ukraine of methods and equipment for RW characterization, as well as of technologies, facilities and containers for various stages of RW management, in particular, for processing, long-term storage and disposal. The aim of these developments is to elaborate an overall RW management system and to ensure effective and safe operation of RW management facilities.

A key point for safety assessments at different steps of RW management is the knowledge of all the relevant properties of materials that are to be disposed of as RW or cleared from regulatory control (immediately or after a certain period of time for decay storage). An improved system for characterization of RW and material for clearance is to be applied for new generated RW and materials. For large existing amounts of accident-related and legacy RW in Ukraine, special provisions and solution need to be established depending on the existing and potential hazards of this RW.

Characterization is the basis for the determination of radiological and non-radiological hazards of the radioactive materials and waste.

Taking into account ultimate importance of RW characterization issues, the "Guideline for characterization, accounting and control of radioactive waste" was developed in the framework of INSC U3.01/10 Project (UK/TS/46) [10].

The Guideline [10], in particular, defines objectives and measures of RW characterization, accounting and control as well as recommendations on the scope of RW characterization within the context of successive achievement of goals at the steps of RW management, taking into account objectives and activities for RW management at the interrelated steps, as follows:

RW management at places of waste generation (pre-treatment and temporary storage of RW);

RW processing (treatment and conditioning);

RW (long-term) storage and disposal;

RW transportation between interrelated steps (only for reference).

In this paper, approaches are considered to carrying out systemized RW characterization at all steps of waste management from generation to disposal so as to ensure safe RW management at each step and compliance of the final RW product with the established requirements.

\section{Goals, sequence and scope of RW characterization}

RW characterization at interrelated steps of its management should ensure the provision of information about RW (RW packages) which is necessary for carrying out an integrated RW management process and which should ensure confirmation that RW or RW packages comply with WAC for processing, long-term storage and/or disposal.

At all steps of RW management, RW characterization is performed with the following goals [2]:

obtaining and maintaining data required for safe RW management at a certain step (ensuring operational safety);

RW sorting taking into account RW classification related to disposal;

providing information for design development and safety assessment of long-term storage and disposal facilities;

verification of compliance of RW with WAC for the next step of RW management and, as far as possible, for further steps up to disposal;

quality control at each RW predisposal step up to disposal;

determination of the possibility for clearance of RW from regulatory control.

RW characterization should ensure availability of sufficient data on RW and RW packages for further steps of RW management and for making appropriate decisions for successive steps of an integrated RW management process. It should in particular include an appropriate recording and archiving system commensurate with the whole period of waste management.

In activities at interrelated steps of predisposal RW management (management of RW at places of its generation, processing, long-term storage) [2], successive characterization of RW (RW packages) should be carried out. 
Characterization of RW (RW form, RW packages) should result in the availability of information about:

RW locations and sources of RW generation; amount (volume and/or weight) of RW;

radiological, physical, chemical, biological and other important properties of RW (RW form, RW packages);

RW is characterized and sorted so that sorted RW, as far as possible, correspond to RW classes related to disposal, taking into account their management at further steps.

Recommendations on the scope and methods of RW characterization are provided in [11]. Examples of equipment for RW characterization are presented in Fig. 2.

Scope of RW radiological characterization, required for safe RW management at different steps of predisposal RW management, is determined by requirements for radiation protection purposes during operation of a facility intended for RW management. The following properties of RW should be defined:

dose rate from RW (RW packages);

specific and total activities of radionuclides.

The scope of RW radiological characterization, required for RW sorting, taking into account RW classification related to disposal, is defined by requirements to long-term safety of RW disposal. To determine the possibility of attribution of RW to certain class related to disposal, data on specific activities of radionuclides, significant for long-term safety of RW disposal, are required (that may make essential contribution to dose estimates for critical groups of population in the long-term post-closure period) [10].

Scope of RW radiological characterization, required for ensuring compliance of RW with the acceptance criteria for the next step of RW management (and, as far as possible, for further steps), is generally defined by the above-mentioned provisions for

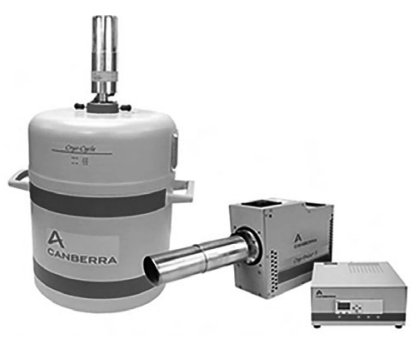

a

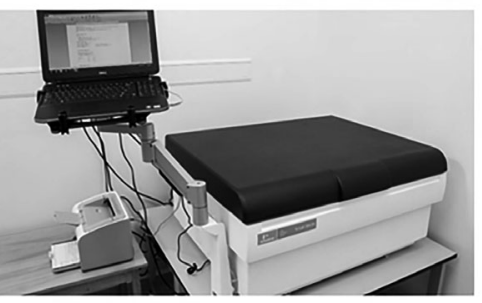

c
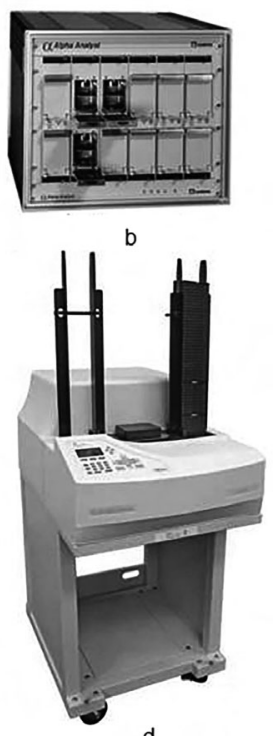

d a - Canberra ${ }^{\circledR}$ HPGe spectrometer

b - Alpha spectrometer (activity concentration of alphaemitters in the radiochemically treated samples)

c - Perkin Elmer Tri-Carb ${ }^{\oplus}$ computer controlled liquid scintillation analyser

d - Alpha-beta counter (activity concentration of alphaand beta-emitters in the radiochemically treated samples)

Figure 2 - Examples of equipment for RW characterization

ensuring operational safety at different steps of RW management and long-term safety of RW disposal.

Scope of radiological characterization of RW (RW packages) at the interrelated steps of its management is summarized in Table 1 [10].

Table 1 - Successive determination of radiological properties of RW (RW packages) at interrelated steps of their management

\begin{tabular}{|c|c|c|c|c|}
\hline \multirow{3}{*}{ No. } & \multirow{3}{*}{$\begin{array}{c}\text { Steps of RW } \\
\text { management }\end{array}$} & \multicolumn{3}{|c|}{ Goals of RW characterization and RW monitoring } \\
\hline & & $\begin{array}{c}\text { Obtaining properties for } \\
\text { safe RW management at } \\
\text { this stage }\end{array}$ & $\begin{array}{c}\text { RW sorting taking } \\
\text { into account RW } \\
\text { classification related to } \\
\text { disposal }\end{array}$ & $\begin{array}{c}\text { Ensuring compliance of RW with } \\
\text { acceptance criteria for the next stage } \\
\text { (and, as far as possible, for further stages) }\end{array}$ \\
\hline & & \multicolumn{3}{|c|}{$\begin{array}{l}\text { Scope of successive radiological characterization of RW (RW packages) at different steps of } \\
\text { RW management }\end{array}$} \\
\hline 1 & $\begin{array}{l}\text { Management } \\
\text { of RW at } \\
\text { places of their } \\
\text { generation }\end{array}$ & $\begin{array}{l}\text { Determination of } \\
\text { following parameters, } \\
\text { taking into account needs } \\
\text { at this stage: } \\
\text { - dose rate; } \\
\text { - surface contamination; } \\
\text { - specific activities of } \\
\text { radionuclides, significant } \\
\text { for operational safety. }\end{array}$ & $\begin{array}{l}\text { Determination of } \\
\text { specific activities } \\
\text { of radionuclides, } \\
\text { significant for long-term } \\
\text { safety of RW disposal. }\end{array}$ & $\begin{array}{l}\text { Use of data, obtained for safe RW } \\
\text { management at this stage and for } \\
\text { RW sorting for disposal, aimed at } \\
\text { demonstration of compliance with } \\
\text { acceptance criteria for the next stage } \\
\text { (and, as far as possible, for further stages) }\end{array}$ \\
\hline
\end{tabular}


Continue of the Table 1

\begin{tabular}{|c|c|c|c|c|}
\hline \multirow{3}{*}{ No. } & \multirow{3}{*}{$\begin{array}{l}\text { Steps of RW } \\
\text { management }\end{array}$} & \multicolumn{3}{|c|}{ Goals of RW characterization and RW monitoring } \\
\hline & & $\begin{array}{c}\text { Obtaining properties for } \\
\text { safe RW management at } \\
\text { this stage }\end{array}$ & $\begin{array}{c}\text { RW sorting taking } \\
\text { into account RW } \\
\text { classification related to } \\
\text { disposal }\end{array}$ & $\begin{array}{c}\text { Ensuring compliance of RW with } \\
\text { acceptance criteria for the next stage } \\
\text { (and, as far as possible, for further stages) }\end{array}$ \\
\hline & & \multicolumn{3}{|c|}{$\begin{array}{l}\text { Scope of successive radiological characterization of RW (RW packages) at different steps of } \\
\text { RW management }\end{array}$} \\
\hline 2 & $\begin{array}{l}\text { RW } \\
\text { processing }\end{array}$ & $\begin{array}{l}\text { Use of previously } \\
\text { obtained data. } \\
\text { Incoming control of RW. } \\
\text { Measurement of dose } \\
\text { rates from RW packages } \\
\text { and contamination of } \\
\text { packages } \\
\text { Adjustment of specific } \\
\text { activities of radionuclides } \\
\text { in RW form, that are } \\
\text { significant for operational } \\
\text { safety. }\end{array}$ & $\begin{array}{l}\text { Use of previously } \\
\text { obtained data. } \\
\text { Adjustment or } \\
\text { determination of } \\
\text { specific activities } \\
\text { of all radionuclides, } \\
\text { significant for long-term } \\
\text { safety of RW disposal. }\end{array}$ & $\begin{array}{l}\text { Use of data, obtained for safe RW } \\
\text { management at this stage and for } \\
\text { RW sorting for disposal, aimed at } \\
\text { demonstration of compliance of RW } \\
\text { packages with acceptance criteria for } \\
\text { specific RW storage facility.* }\end{array}$ \\
\hline 3 & $\begin{array}{l}\text { Long-term } \\
\text { storage of RW }\end{array}$ & $\begin{array}{l}\text { Incoming control of RW } \\
\text { packages. } \\
\text { Adjustment, if necessary, } \\
\text { of RW properties, } \\
\text { significant for operational } \\
\text { safety }\end{array}$ & & $\begin{array}{l}\text { Use of data, obtained safe RW } \\
\text { management at this stage and for } \\
\text { RW sorting for disposal, aimed at } \\
\text { demonstration of compliance of RW } \\
\text { packages WAC for specific RW disposal } \\
\text { facility.* }\end{array}$ \\
\hline 4 & RW disposal & $\begin{array}{l}\text { Incoming control of RW } \\
\text { packages }\end{array}$ & & Incoming control of RW packages \\
\hline
\end{tabular}

* for designing and safety assessments of long-term storage and disposal RW facilities

Scope of RW chemical characterization, aimed at long-term storage and/or disposal, is defined by the requirements aimed at ensuring safety of storage and long-term safety of RW disposal. In RW (RW packages), content of chemical substances is limited (or excluded) to ensure:

chemical compatibility of RW components (RW form) with each other and with materials of packaging set or structures where RW are located (chemical compatibility means very slow rate or absence of chemical reactions between different materials that lead to corrosion and degradation of barriers and release of radionuclides);

limitation and minimization of leaching of radionuclides from $\mathrm{RW}$ form;

limitation and minimization of gas generation in RW; prevention of fire, explosion.

The scope of RW chemical characterization, required for ensuring compliance of RW with acceptance criteria associated to RW processing steps, is defined so as to ensure prevention of accidents at RW processing facilities: fire, explosion, failures of safety-related components of the facility as a result of chemical reactions.

The scope of RW biological characterization, required for ensuring compliance of RW with acceptance criteria associated to RW processing, long-term storage and/or disposal steps, is defined to ensure:

prevention of any adverse effects due to biological hazardous properties of RW;

minimization of microbiological degradation of RW component or matrix material that may cause disruption of structural stability of RW form.

In RW, it is limited the content of:

organic and biological substances, in particular, putrescible substances;

pathogenic microorganisms, which activities may cause infections of personnel, etc.

The scope of RW physical characterization, in view of long-term storage and/or disposal, is required by the requirements aimed at ensuring safety of storage and long-term safety of RW disposal. If RW form serves as a barrier according to the established criteria, the following should be characterized:

structural stability;

mechanical strength;

thermal stability;

radiation stability;

microbiological stability;

homogeneity;

minimization of porosity, voids. 
The scope of RW physical characterization, required for ensuring compliance of RW with acceptance criteria for the different RW processing steps, is defined according to the WAC dealing with the specific RW processing facilities (e.g. compaction, incineration) [10].

\section{Approaches to RW characterization during its management at places of its generation}

The main goals of RW management at places of its generation (see Section 7 of this Guideline) are the following:

control of RW streams generation and its properties within the prescribed limits;

minimization of volumes of RW leading to a reduction of needed storage volumes for RW;

minimization of activity of radionuclides in RW; obtain all necessary information and data in order to perform a proper characterization and sorting of RW; ensuring RW confinement during the period of temporary storage;

facilitation of further RW processing and increase of its efficiency.

Technical and organizational measures of RW management at places of its generation include pre-treatment and temporary storage of RW at the producer's site, namely:

minimization of RW generation;

RW collection;

RW fragmentation (if necessary);

RW characterization;

RW sorting according to the above defined criteria;

RW sorting, preparation and if considered as appropriate, decontamination aimed at clearance of decontaminated material from the regulatory control; accounting and control of RW generation and relocation;

RW temporary storage after its pre-treatment;

safe transportation of RW on site and/or transportation of RW (RW packages) out of the site.

According to the results of a (preliminary) characterization and sorting, RW should be divided into typical groups as follows:

clearance from the regulatory control;

long-term storage;

direct shipping for disposal;

further processing depending on available techniques and facilities for RW processing.

Characterization and sorting of RW, accumulated in existing RW temporary storage facilities should be carried out during its retrieval and at the beginning of technological process of their processing. A preliminary or initial characterization, which should take into account also historical information, may be carried out before starting RW retrieval process.

Temporarily stored solid RW, accumulated during past practices, can be removed and transferred to
RW processing facilities predominantly without sorting, if RW sorting is envisaged at RW processing facilities. In this case, it is envisaged to carry out RW characterization of sorted RW at RW processing facilities prior to their transfer to specific RW treatment units (e.g. compaction, incineration, etc.).

The main objective of RW characterization during RW management at places of its generation is to define further processing and disposal options. For this purpose, the recommended list of typical properties of RW, to be defined at places of its generation, is presented in the Guideline [10]. This list of properties is not understood as mandatory requirement for definition, since this depends on specific conditions. At further steps of RW management, some specific properties may be added or removed from this list.

RW characterization should be performed in order to establish properties for the RW management at next steps (this might be also for transportation or long-term storage/disposal) if no RW processing is foreseen. If RW is transferred to processing (RW processing facility) WAC should be defined and compliance of RW with them demonstrated.

At the step of RW management at places of its generation, before its processing, RW sorting is carried out taking into account transfer of sorted RW to specific RW processing units (e.g. for compaction or incineration).

During RW sorting, there should be determined additional radiological properties of sorted RW, required for planning of operational safety at RW treatment facilities (taking into account estimated changes of RW characteristics during their processing).

Radiological properties of RW, determined for planning of operational safety during management of RW at places of their generation and at RW processing facilities, are applicable for planning of operational safety at the steps of long-term storage and disposal of RW.

During RW sorting at places of its generation (or during sorting of already accumulated RW at RW processing facility), the specific activity of present radionuclides, significant for long-term safety of RW disposal, should be determined. RW sorting should be carried out in order that RW is assigned to a certain class related to disposal (taking into account changes in specific activities of radionuclides in RW form after processing - e.g. after incineration).

At the step of RW management at places of its generation, chemical properties of RW for further RW processing at specific facilities are determined to:

prevent accidents at these facilities (fire, explosion, etc.);

obtain final RW product as a result of processing that complies with the acceptance criteria for longterm storage and/or disposal.

During RW sorting, there are determined materials/substances that pose hazard of explosion and/or fire during processing at specific facility. 
During RW sorting, there are determined materials/substances that may be incinerated (organic, combustible, flammable, etc.).

DuringRW sorting, therearedetermined chemically active substances (strong oxidizers; substances that are unstable under normal conditions and those subject to intense transformations; substances that are capable of self-induced detonation or explosive reaction under normal temperature and pressure or under the action of thermal or mechanical shock; have negative reaction inside RW form and/or with the material of container (gas generation, corrosion, increase of radionuclide mobility).

RW with content of chemically active substances is processed by ensuring neutralization of these substances.

At the step of RW management at places of its generation, physical properties of RW are determined for further RW processing at specific facilities. As a rule, solid RW are sorted into combustible/non-combustible, compactable/non-compactable, metal waste.

During RW sorting for its processing at specific facility, the following is determined:

RW dimensions aimed at non-exceeding permissible dimensions (if necessary, RW are fragmented);

RW materials to segregate combustible/noncombustible materials;

non-combustible RW material with regard to the acceptability of their physical and/or geometrical properties for transfer to the compaction facility [10].

\section{Approaches to RW characterization during processing}

RW processing is carried out for: reduction of radiological impacts of RW; removal of radionuclides from $\mathrm{RW}$;

RW volume reduction;

change of RW composition;

transformation of RW into form, which is suitable for transportation in compliance with transport regulations and is acceptable for long-term storage and/or disposal and is characterized by chemical, thermal, radiation stability during transportation, longterm storage and disposal of RW;

ensuring of passive safety, containment of RW;

cost saving for long-term storage and disposal of RW.

Technological operations at the stage of RW processing include the following, depending on the processing techniques:

RW removal from their temporary storage locations; acceptance of RW to the facility for RW processing; characterization of RW that are accepted for processing, taking into account data on RW characteristics that were obtained at previous step of RW management at places of its generation;

RW sorting and fragmentation taking into account
RW acceptance criteria for processing and sorting, carried out at the previous step of RW management at places of its generation;

RW volume reduction (compaction, incineration etc.) and/or (partial) removal of radionuclides;

decontamination of RW;

transformation of RW into certain physical and chemical form;

placement of RW (RW form) into packaging set;

characterization of RW form and RW packages;

temporary storage of RW packages up to their transfer for long-term storage and/or disposal;

control and accounting of RW (RW packages);

transfer of RW (RW packages) to special enterprise for long-term storage and/or disposal.

Conditioning may include conversion of RW to a solid waste form, immobilization of RW, enclosure of RW in containers, and, if necessary, providing an overpack.

Processing of RW should ensure to obtain RW packages, which comply with current RW acceptance criteria for further long-term storage and/or disposal, including:

ensuring safe long-term storage of RW packages in the storage facility;

removal of RW packages from the storage facility after termination of long-term storage for their transfer for disposal;

confinement of radionuclides inside RW packages within the established limits both under normal conditions and in case of emergencies that may happen during handling, transportation, long-term storage and disposal.

In case of absence of RW acceptance criteria for storage and/or disposal, criteria are applied, defined on basis of justified assumptions regarding the planned option for RW storage and/or disposal.

The main goal of RW characterization at the step of its processing is confirmation that RW packages (including RW form, packaging set) comply with WAC for long-term storage and/or disposal. In its turn, acceptance criteria of RW packages for long-term storage should take into account further RW disposal after termination of long-term storage.

During RW processing RW properties are changing to a different extent. This should be taken into account when carrying out characterization of RW packages obtained as a result of RW processing [10].

Radiological properties of each RW package should be determined by measurements and/or assessments of:

the radionuclide inventory of the package (total and specific activities of radionuclides);

RW package dose rates;

type of surface contamination (fixed or non-fixed) and levels of surface contamination on external package (container) surfaces;

heat generation of a RW package. 
Determination of specific activities of radionuclides in RW packages can be carried out by measurement of activities of gamma-emitting radionuclides (key radionuclides) and calculations of activities of alpha- and beta-emitting radionuclides using scaling factors (nuclide vector). Scaling factors are based on the results of investigation of specific activities of radionuclides in samples, taken from processed and/ or non-processed RW.

Determination of specific activities of radionuclides in packages with processed RW is carried out to confirm compliance of processed RW with WAC for specific RW long-term storage and/or disposal facility.

Determined radiological properties of RW may be used also for designing and safety assessment of long-term storage and disposal facilities (in particular, when processing is performed not having available final WAC of a distinct facility).

Chemical properties of RW form after its processing should be defined in terms of stability of long-term storage of radioactive waste and/or disposal of packaging waste. Special attention should be paid to determination of limited content or absence of such substances as:

organic, in particular, those capable of decomposition accompanied by gas generation or generation of compounds that pose hazard for container or can increase mobility of radionuclides in RW form or in the medium of disposal facility, as well as explosion or ignition hazardous substances;

corrosive active substances (inorganic acids, alkalis, etc.);

complexing substances that lead to increase of mobility of radionuclides, corrosion activity of the medium;

chemical components that react inside RW form and/or with other barriers of storage/disposal facility with undesirable consequences (gas generation, corrosion, increase of radionuclide mobility, etc.). Examples include metals or ion-exchange materials that react with RW matrix with formation of bigger amount of reaction products that may then damage RW package; graphite that may be bounded by Wigner energy; as well as materials that may have essential impact on $\mathrm{pH}$ of RW form or pose hazard for container integrity;

chemically active substances (strong oxidizers; substances, unstable under normal conditions, subject to intense transformations, capable of spontaneous detonation or explosive reaction at normal temperature and pressure or under impact of thermal or mechanical shock, etc.);

explosive, flammable, combustive, aggressive and pyrophoric substances: including any RW components that may develop to form materials with such properties within a long-term period;

toxic substances, which may have an environmental impact.
The physical characteristics of RW form after its processing can be defined in terms of stability of RW form during long-term storage and/or disposal of RW packages [10].

Special attention should be paid to determination of the following physical characteristics of RW form (if RW form serves as a barrier):

indicators that characterize mechanical strength of RW form (compressive strength, bend strength, Young modulus, etc.);

indicators that characterize structural stability and longevity of RW form (matrix homogeneity; resistance to cyclic mechanical and thermal impacts; radiation, microbiological, chemical stability, etc.);

indicators that characterize homogeneity, porosity and permeability of RW form, minimization of voids in it.

Above-mentioned indicators that characterize physical properties of RW form are determined to demonstrate the following properties of RW form during handling of RW package both under normal and accident conditions:

ensuring sufficient strength of RW form (when it is located in the container) during handling operations, stockpiling, disposal in several tiers with organization of cap;

longevity of RW form (in case of its very slow evolution) under defined conditions of external chemical, mechanical, thermal, radiation, microbiological impacts);

stability of geometrical characteristics and structure (minimization of matrix defects, cracks formation) of RW form under defined conditions of external impacts, as well as processes that occur directly inside RW form (gas generation, radiation degradation, etc.).

Data on physical and chemical characteristics of RW form are determined in scope sufficient for predicting long-term behavior of RW form [10].

For non-immobilized RW (e.g. untreated RW in containers intended for direct disposal or RW «in bulk» for storage or disposal in the facilities for very low level RW), the waste itself comprises RW form. However, in this case, RW form does not perform the barrier function, and the above-mentioned physical properties are defined by packaging sets (containers) and/or other barriers of the disposal facility.

\section{RW characterization at the step of long-term storage of RW}

Long-term storage of RW is aimed at:

providing RW containment within RW package and RW isolation during the established period (30 years and more);

further removal of RW packages from the storage facility for their transfer for disposal.

RW confinement and isolation during long-term storage should rely on structures and equipment 
of the storage facility, as well as on integrity of RW forms and RW packages. This should be maintained during the established storage period up to transfer of RW packages for disposal.

During long-term storage of RW, control of fulfilment of envisaged safety functions by the protective barriers of the storage facility is performed, as well as compliance of RW packages, contained in the storage facility, with the established criteria. At that, it is necessary to consider interaction between RW forms, packaging sets and media where they are placed (e.g. corrosion processes due to chemical or galvanic processes) [10].

Technological operations with RW packages at the stage of long-term storage of RW include:

reception of RW packages, incoming control and check-up of compliance of properties of RW packages with the acceptance criteria for long-term storage;

loading (placement) of RW packages for longterm storage;

storage of RW packages during the period established by the design, until their transfer for disposal;

periodical control of RW packages during their long-term storage according to the established criteria and procedures;

removal of RW packages for their transfer for disposal or for control of the packages;

repackaging of RW packages (if necessary);

accounting of RW packages;

safe transportation of RW packages to the storage site for disposal and carrying out transport and technological operations during disposal.

Characterization of RW packages at the stage of long-term storage, as a rule, includes only control of RW packages and control of their state during longterm storage. At that, determination of properties of RW packages could also be carried out if additional data are required for demonstration of compliance with WAC for RW disposal [10].

\section{Conclusions}

1. In Ukraine, there is a huge variety of RW, including large amount of RW, which need to be properly characterized and sorted. There is on-going development in Ukraine of methods and equipment for RW characterization, as well as technologies, facilities and containers for various stages of RW management.

2. Standards and Methodologies for characterization of different RW streams are under development by different RW entities.

3. The "Guideline for characterization, accounting and control of radioactive waste" provides methodological basis for RW characterization in Ukraine. As it is a "living" document, it may be further amended and supplemented on base of newly obtained experience in the field of Ukrainian RW characterization.

4. Methodological approaches for the determination of RW properties, suggested in this paper, may be used as general recommendations for characterization of RW already accumulated in Ukraine and of RW expected to be generated in Ukraine in the future.

\section{References}

1. Law of Ukraine "On the State Targeted Ecological Program of radioactive waste management", Journal of the Verkhovna Rada of Ukraine, 2009, No. 5. (Ukr).

2. General Safety Provisions for Predisposal Radioactive Waste Management, NP 306.4.213-2017, approved by SNRIU Order No. 279 dated 01.08.2017. (Ukr).

3. Joint Convention on the Safety of Spent Fuel Management and on the Safety of Radioactive Waste Management, IAEA, Information Circular, adopted on 5 September 1997 by a Diplomatic Conference convened by the International Atomic Energy Agency, $36 \mathrm{p}$.

4. Convention on Nuclear Safety, IAEA, Information Circular, adopted on 17 June 1994 by a Diplomatic Conference convened by the International Atomic Energy Agency, $14 \mathrm{p}$.

5. Strategy and Methodology for Radioactive Waste Characterization, IAEA-TECDOC-1537, IAEA, 2007, 178 p.

6. Characterization of Radioactive Waste Forms and Packages. Technical Reports Series No. 383, IAEA, 1997, 138 p.

7. Determination and Use of Scaling Factors for Waste Characterization in NPPs, IAEA-NW-T-1.18, STI/PUB/1363, Vienna, 2009.

8. Council Directive 2013/59/Euratom of 5 December 2013, laying down basic safety standards for protection against the dangers arising from exposure to ionising radiation, and repealing Directives 89/618/Euratom, 90/641/ Euratom, 96/29/Euratom, 97/43/Euratom and 2003/122/ Euratom. Official Journal of the European Union L-13 of 17 January 2014.

9. Council Directive 2011/70/Euratom of 19 July 2011, establishing a Community framework for the responsible and safe management of spent fuel and radioactive waste, $9 \mathrm{p}$.

10. Guideline for Characterization, Accounting and Control of Radioactive Waste. Revision 3, developed in the framework of INSC Project U3.01/10 (UK/TS/46, Subtask 2.1), November 2017, 40 p.

11. Recommendations on Establishment of Acceptance Criteria for Disposal of Conditioned Radioactive Waste in Near-surface Facilities, RD 306.4.098-2004, approved by SNRIU Order No. 160 dated 25.10.2004. 


\section{Підходи до характеризації радіоактивних відходів в Україні на взаємопов'язаних стадіях поводження 3 ними}

Ярмош І. В. ${ }^{1}$, Кондратьєв С. М. ${ }^{1}$, Кюхлер Л. ${ }^{2}$, Токаревський О. В. ${ }^{2}$, Соловйов О. С. ${ }^{2}$

1 Державне підприємство «Державний науково-технічний центр 3 ядерної та радіаційної безпеки», м. Київ, Україна

${ }^{2}$ Gesellschaft für Anlagen- und Reaktorsicherheit (GRS) gGmbH, Berlin, Germany

Потреба в подальшій розробці комплексної системи поводження з радіоактивними відходами (далі - РАВ) в Україні відображена в українських нормативно-правових актах, зокрема в Законі України «Про Загальнодержавну цільову екологічну програму поводження 3 радіоактивними відходами» та «Загальних положеннях безпеки при поводженні з радіоактивними відходами до їх захоронення».

Ключовим елементом оцінок безпеки на різних стадіях поводження з РАВ $\epsilon$ знання всіх важливих характеристик радіоактивних матеріалів, які будуть розміщуватися на захоронення як РАВ або звільнятися від регулюючого контролю.

Характеризація $\epsilon$ базисом для визначення радіологічних та нерадіологічних небезпек радіоак- тивних матеріалів та відходів.

Характеризацію РАВ на взаємопов'язаних стадіях поводження з ними виконують для забезпечення отримання інформації про РАВ (упаковки РАВ), яка $\epsilon$ необхідною для реалізації інтегрованого процесу поводження з РАВ.

У цій статті розглядаються підходи до виконання систематизованої характеризації РАВ на всіх стадіях поводження з ними від утворення до захоронення, щоб забезпечити безпеку поводження з РАВ на кожному етапі та відповідність кінцевого продукту РАВ встановленим вимогам, зокрема критеріям приймання РАВ на наступні стадії поводження з ними.

Інформація, в статті, базується на положеннях рекомендаційного документа «Керівництво з характеризації, обліку та контролю радіоактивних відходів», розробленого в рамках проекту INSC U3.01/10 (UK/TS/46) експертами ДНТЦ ЯРБ та РИСКАУДИТ.

Ключові слова: характеризація радіоактивних відходів, Керівництво з характеризації, методологічний підхід, рекомендації, поводження з РАВ, радіологічні властивості, фізичні властивості, хімічні властивості. 